\title{
Alteration of Coral Reef Community Structure Caused by Athropogenic Activity in the Coastal Area of Giliketapang Island, Probolinggo, East Java, Indonesia
}

\author{
Lutfiatul Puspitasari, Setijono Samino, Catur Retnaningdyah*
}

Biology Department, Faculty of Mathematics and Natural Sciences, Brawijaya University, Malang, Indonesia

\begin{abstract}
The aim of the research was to know the effect of anthropogenic activity around the coastal area of Giliketapang Island toward community structure of coral reefs. This study used belt transect method which consisted of 18 transects in three locations (harbour, near the forest, and transitionol areas) at $50-80 \mathrm{~m}$ from the coast, with a plot sized of $2 \times 2 \mathrm{~m}^{2}$. Abundance of coral reefs were observed based on their coverage. There were 11 families of coral reefs found. The percentage of coral damage decreased and the number of the species increased at the zones far from the coast. This also affected the coverage value of coral reefs. Coral coverage at the harbour and near the forest was $53.06 \%$ and 65 . $36 \%$ respectively, whereas in the transitional area was $38.38 \%$. Co-domination between Porites lobata and Chyphastrea microphthalma occurred at the harbour, while Poritesmayeri and Acropora spp. codominated in the location near the forest. Poritidae family dominated the transition area. Anthropogenic activities at transitional location caused severe damage toward coral reefs.
\end{abstract}

Keywords: coral reef, damage, Giliketapang Island

\section{INTRODUCTION}

Giliketapang island is a small island located 3.8 miles from the north of Probolinggo. Giliketapang island is formed by coral rocks, so the surrounding water is filled with a variety of reef life. The majority of people living in this island are fishermen. However, most fishermen do their activities without regard to the effects of their activities toward the environment, such as the use of some explosives causing the existence of coral reefs of no more than 40\% [1]. Anthropogenic activity is not only shipping, but also waste disposal, public toilets, and coral mining. One of the real impacts to the living organisms around is the decrease in fish diversity around the coral reefs; due to the fact that coral reef ecosystem is a source of living for the organisms in its surrounding areas. Therefore, the purpose of this study was to determine the effects of anthropogenic activities toward coral reefs.

\footnotetext{
"Corresponding author: Catur Retnaningdyah

Biology Department, Faculty of Math. and Natural Sciences, Brawijaya University, Jl. Veteran, Malang, Indonesia 65145 Email: catur@ub.ac.id
}

\section{MATERIALS AND METHODS}

The research used belt transect method which consisted of 18 transects in tree locations (harbour, near the forest and settlement) (Fig.1) at the distance of 50-80 meters from the coast, with a plot size of $2 \times 2 \mathrm{~m}^{2}$. The coverage of coral reefs for each location and station was observed using a visual technique [2]. The observation was done by diving in the depth of 3-7 meters, using aSCUBA equipment. Coral reef identification was done based on a book from Veron [3] and Suharsono [4].

The use of tree locations was based on the reason that each location has different anthropogenic activities. Location I was harbour, located in the north of Giliketapang Island, having a substrate type of sand. There was a high anthropogenic activity found in this location and it has a depth of about 4-5 m. Location I consisted of 5 transects with 10 stations for each transect. The distance between transects was 10 meters.

Location II was near the forest and is located at a site east from Giliketapang Island and has depth about 3-4 m. This location has light slope. Based on the level of the anthropogenic activity, fishing activity was found to be rare and there 
was not any human beings' activities done in this location. This location consisted of 8 transects with 10 stations for each transect. The distance between transects was 5 meters.

Location III was near a settlement having a substrate type of sand with high shipping activities since it has a depth of $>5 \mathrm{~m}$. This area is intermediate between settlements and homogeneous forests. This location consisted of 5 transects with 8 stations for each transect. The distance between transects was 5 meters.

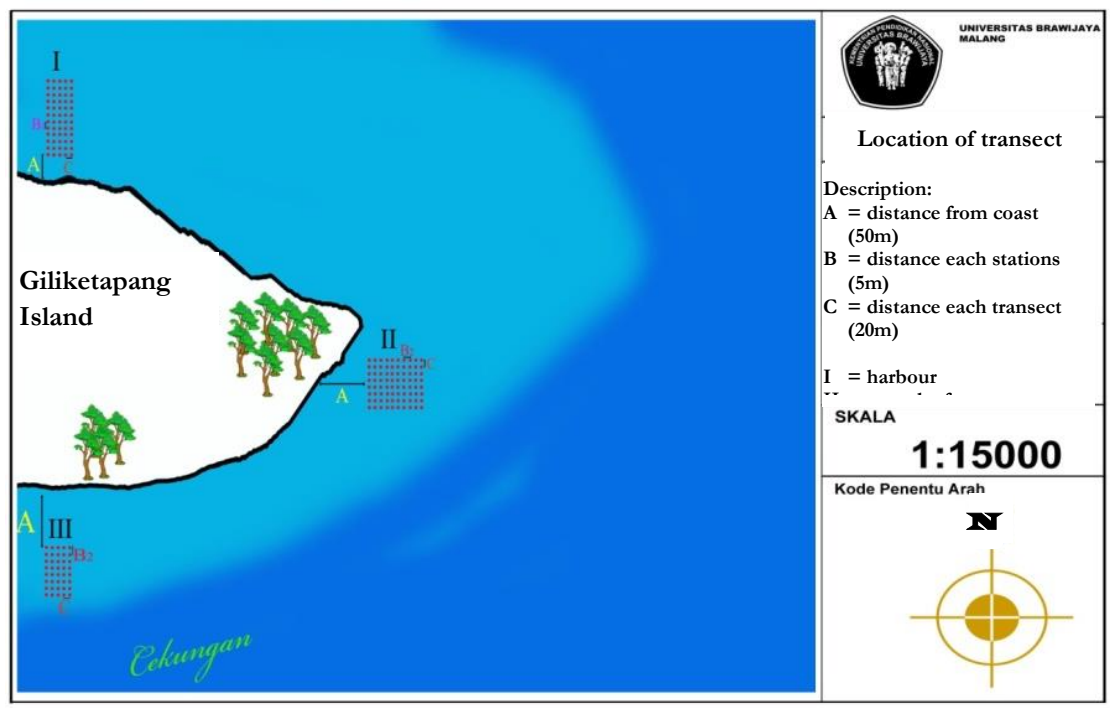

Figure 1. Coverage area of study in Giliketapang Island

\section{RESULTS AND DISCUSSION}

Coral reefs found in Giliketapang island were as many as 11 families; among those families were Acroporidae, Agaciidae, Astrocoeniidae,
Faviidae, Fungiidae, Pocilloporidae, Poritidae, Siderastreidae, Oculinidae, Mussidae, and Merulinidae (Table 1).

Table 1. Diversity of coral reefs (filum: Coelenterata) in Giliketapang Island

\begin{tabular}{|c|c|c|c|c|c|c|c|}
\hline No. & Family & Genus & Species & No. & Family & Genus & Species \\
\hline 1. & Acroporidae & Acropora & Acroporaspp. & 25. & Faviidae & Leptrastrea & Leptastreasp. \\
\hline 2. & & Mantipora & M. digitata & 26. & & & L. purpurea \\
\hline 3. & & & M. malampaya & 27. & & Montastrea & Montastreaspp. \\
\hline 4. & & & M. porites & 28. & & Favites & Favitessp. \\
\hline 5. & & & Mantiporasp. & 29. & & Favia & Faviasp. \\
\hline 6. & & & M. turtlensis & 30. & Fungiidae & Cycloseris & C. costulata \\
\hline 7. & & & M. stellata & 31. & & Herpolitha & Herpolithasp. \\
\hline 8. & Agariciidae & Coeloseris & Coeloseri ssp. & 32. & & Diploastrea & D. heliopora \\
\hline 9. & & Pavona & P. decussata & 33. & Pocilloporidae & Pocillopora & P. damicornis \\
\hline 10. & & & P. frondifera & 34. & Poritidae & Porites & P. (synarea) rus \\
\hline 11. & & & P. varians & 35. & & & P. compressa \\
\hline 12. & Astrocoeniidae & Stylocoeniella & Stylocoeniella sp. & 36. & & & P. cylindrica \\
\hline 13. & Faviidae & Cyphastrea & C. microphthalma & 37. & & & P. lobata \\
\hline 14. & & & C. japonica & 38. & & & P. mayeri \\
\hline 15. & & Favites & F. abdita & 39. & & & P. nodifera \\
\hline 16. & & & F. complanata & 40. & & & Poritesspp. \\
\hline 17. & & Goniastrea & G. aspera & 41. & & & P. stephensoni \\
\hline 18. & & & G. palauensis & 42. & & Alveopora & Alveopora spp. \\
\hline 19. & & & G. retiformis & 43. & & Ganiopora & G. tenuidens \\
\hline 20. & & & Goniastrea sp. 1 & 44. & Siderastreidae & Psammocora & P. profundacella \\
\hline 21. & & & Goniastrea sp. 2 & 45. & Oculinidae & Galaxea & G. astreata \\
\hline 22. & & & Goniastrea sp. 3 & 46. & & & Galaxea sp. \\
\hline 23. & & & Goniastreasp. 4 & 47. & Mussidae & Lobophyllia & L. flabelliformis \\
\hline 24. & & & Goniastreasp. 5 & 48. & & & L. hemprichii \\
\hline & & & & 49. & Merulinidae & Hydnophora & H. microconos \\
\hline
\end{tabular}


Poritidae was a family having the largest number of species compared to the other families. Poritidae is one type of coral reefs having a massive form and sheets, especially in the Porites genus. This species has the composition of coral species coralite varying in sizes without any conesteum. Walls and septa of coralit shaped its porous. The special characteristic of septa is on its erger and each genus has a typical shape of this structure. Poritidae is a family among which having the smallest polyps [4,5]. In location I (harbour), occurred co-domination between P.lobata and C.micropbthalma, while P.mayeri and Acropora spp. co-domination was found in location II (near the forest). Acropora spp. is one type of coral reefs having a fast capability to grow and one of the coral reefs which is extremely sensitive to environmental changes-such the changes shall happen in the environment [6]. Acropora spp. usually live in areas having frequent breaking waves, with sand and clear water. This kind of coral reef is classified as highly vulnerable to pollution, sedimentation, and fishing in the form of human activities [7]. If Acropora spp. is found in a place, then it can be said that water condition in that particular place is good and suitable for the growth of Acropora spp. coral species. Location III (settlement) was dominated with the existence of Poritidae family (Figure 2). If Poritidae family is found to be dominant in territorial water, it indicates that site is contaminated [8].
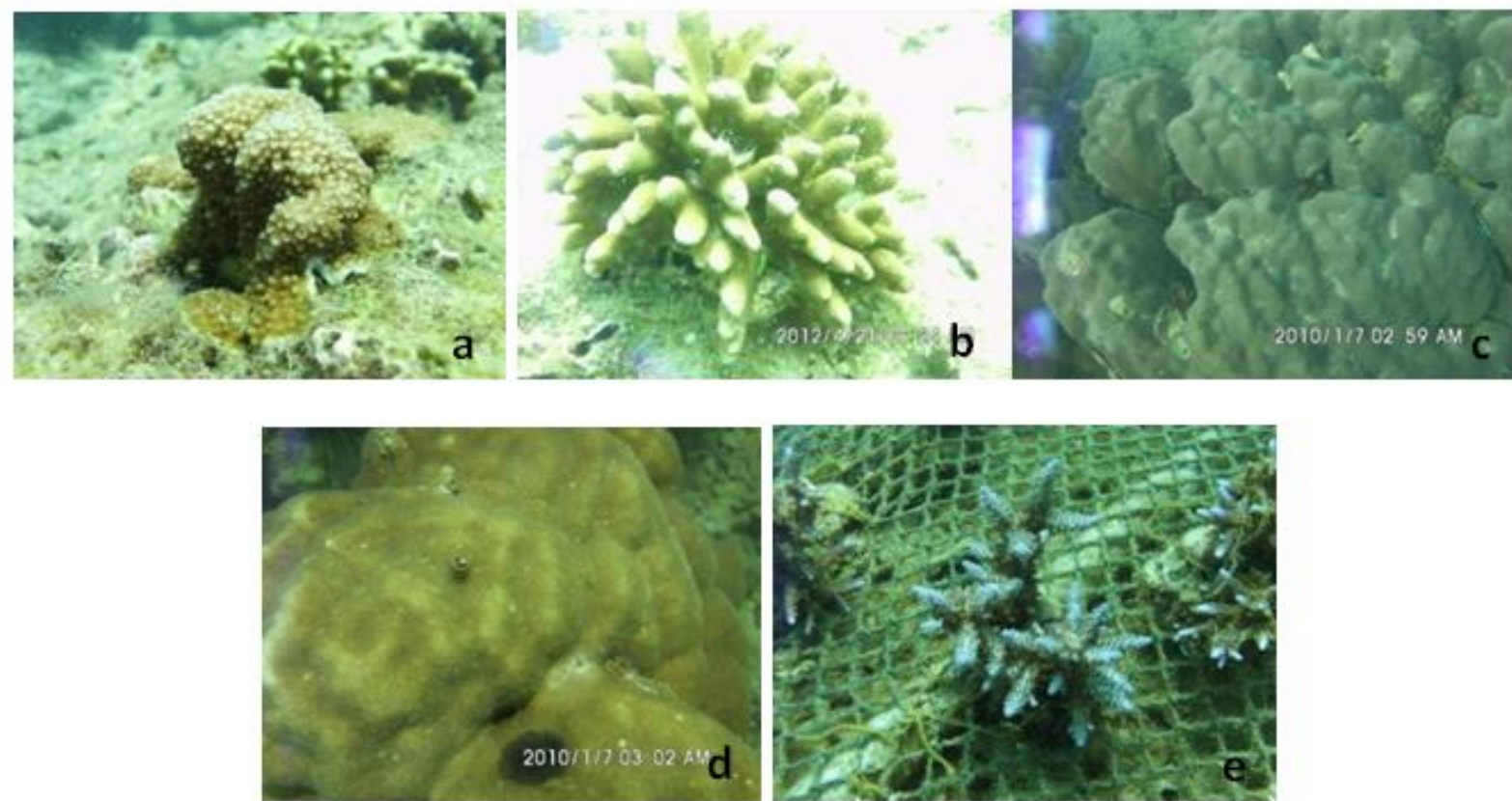

Figure 2. Dominant species of coral reef in Giliketapang Island; (a) C. micropbthalma; (b) P. compressa; (c) P. lobata; (d) P. mayeri; (e) Acropora spp.

The increasing percentage of coral reefs damage caused the decrease in the number of species in each location. Coral reefs damage (bleaching) would decrease in the location far from the coast. At the distance of 70 meters from the coast, the damage began to decline which was characterized by the non-existence of coral bleaching (Figure 3a and 3b). It was caused by the decrease of the anthropogenic activities and as such the varieties of species increased. Activities causing the damage to coral reefs include waste disposal, public toilets activities, coral mining, and shipping activities. The decrease of coral reefs can occur because of disruption caused by the activities of public and environmental conditions. Interference can cause stress to the organisms and that can cause changes toward the qualitative and quantitative structures and functions of a community. Stress on coral reefs can occur due to sedimentation, the influx of fresh water, changes in temperature, and light penetration [9]. Meanwhile, according to Leksono [10], environmental disorders not only cause changes in a community structure, but can also cause changes in the physical environment around it. In marine ecosystems, cyclone disturbance affects the coverage area of coral reef ecosystems. Coral reefs unprotected by the island are more vulnerable to damage than those which are protected by the island. The more number of coral reef species, the greater their coverage will be. 
At a distance of 80 meter from the coast, the number of coral reef species increases. It may be reasonable to assume that the farther the distance then the higher the carrying capacity of the corals reduced. However, based on (Fig. 4), the closing value at a distance of 80 meter from the coast was found to be the highest value compared to the closing value without distances. At distances of 50 and $60 \mathrm{~m}$ from the coast, at location III, the coral reef coverage was $0 \%$; in both of these distances sand dominated the environment, so there were not any coral reefs found.
The number of coral reef species will affect the percentage of coral reefs in covering each location. The more number of coral reef species, the greater the value of its coverage. The magnitude of the coverage of living and dead coral reefs was shown by the value of their coverage in each location and each transect in each location. Based on the criteria from Kreb [11], coral reefs coverage in location I and II was in good condition (53.06\% and 65.36), while in location III was not $(38.38 \%)$.
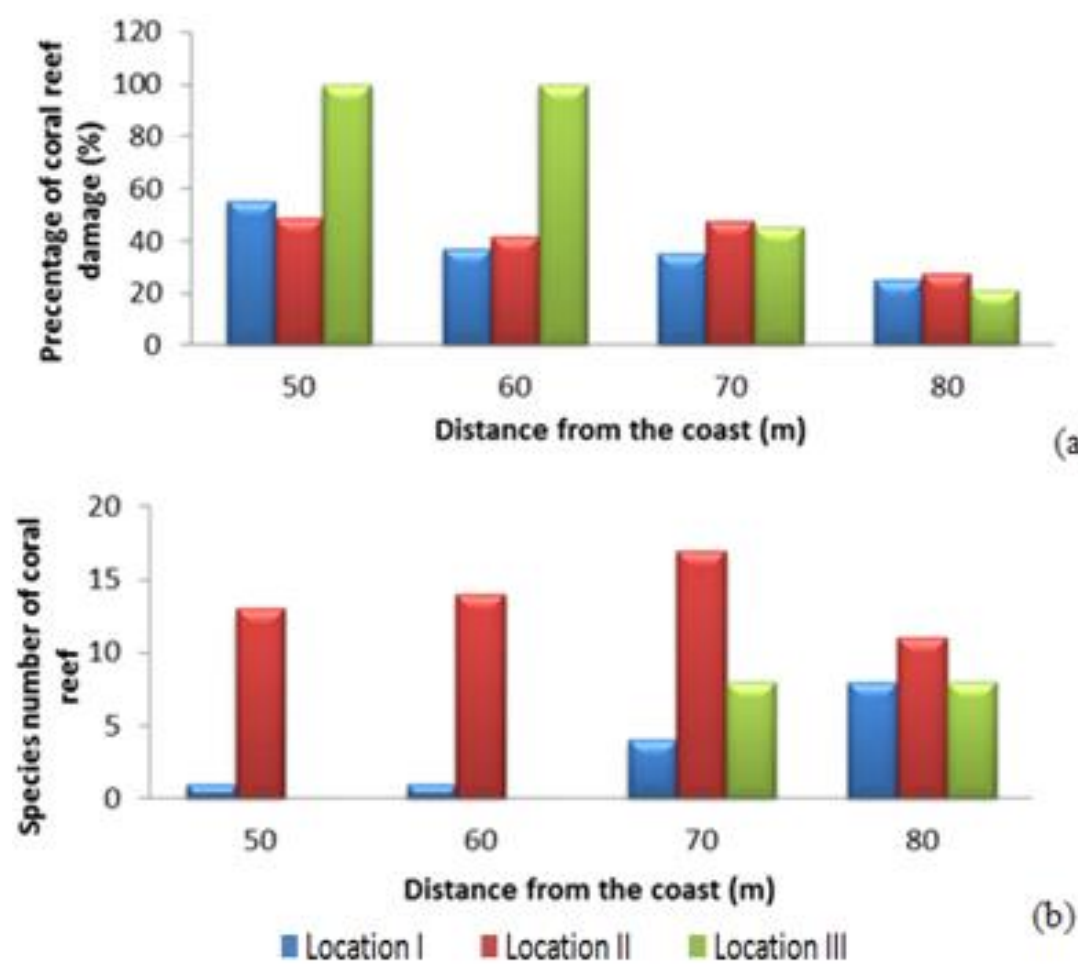

(a)

(b)

Figure 3. Comparison of the percentage of coral reef damage (a) and number of coral reef species (b) based on the distance from each location in Giliketapang island (Location I= harbour; Location II= near the forest; Location III= settlement).

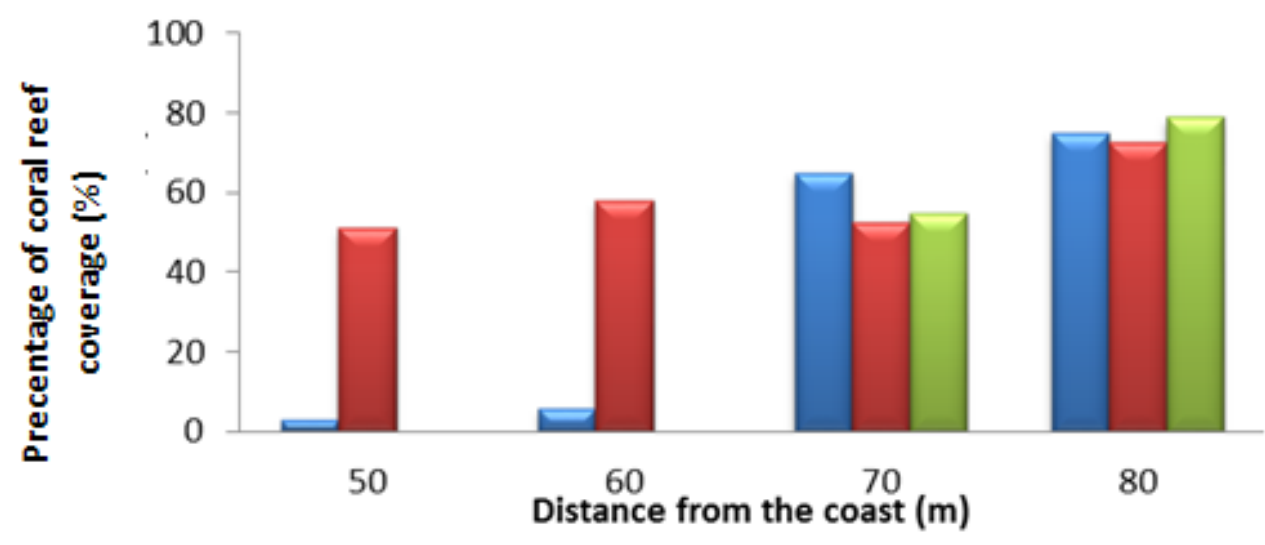

- Location I L Location II In Location III

Figure 5. Percentage ofcoral reefs coverage based on the distance from each location in Giliketapang island (Location I= harbour; Location II= near the forest; Location III= settlement). 


\section{CONCLUSION}

Anthropogenic activities especially the ones found in the settlement area can influence the community structure of coral reefs. The effect of anthropogenic activities in harbour and near the forest were less damaging than the ones in the settlement area. Activities causing damage to coral reef include waste disposal activities, public toilets activities, coral mining activities, and shipping activities. Coral reefs coverage in location I and II was in good condition (53.06 $\%$ and 65.36), while in location III was not (38.38\%). Co-domination between $P$. lobata and C. microphthalma occurred in location I, P. mayeri and Acropora spp. co-domination was found in location I, and the existence of Poritidae family dominated location III.

\section{ACKNOWLEDGMENTS}

Thanks to Drs.Setijono S., M. S. DSc., and Dr.Catur R., M. Si who have helped improving this manuscript.

\section{REFERENCES}

1. Dinas Perikanan dan Kelautan (2010) Profil Pulau Giliketapang Kabupaten Probolinggo, Pemerintah Kabupaten Probolinggo, Probolinggo.

2. Hill J, Clive W (2004) Methods for ecological monitoring of coral reefs. Australian Institute of Marine Science Press. Australia.

3. Veron, J. E. N (2000) Coral of The World, Australian Institute of Marine Science, Australia.

4. Suharsono (2010) Jenis-jenis terumbu karang di Indonesia. LIPI Press. Jakarta.

5. Calfo AR (2002) Book of coral propagation: A concise guide to the successful care and culture of coral reef invertebrates (Vol. 1). PA: Reading Trees Monroeville. Pennsylvania.

6. Sya'arani L (1992) Bentuk rangka dan pertumbuhanAcropora aspera (Dana) di Laut Jawa pada musim barat. Bunga Rampai Pola Ilmiah Pokok. Universitas Diponegoro. Purwokerto.

7. Mukhlis (2010) Ekosistem terumbu karang di kawasan wisata bahari Gili Trawangan, Lombok dan pengaruh hidrokarbon pada masa lethal karang Acropora spp.. Doctoral Thesis. Universitas Negeri Malang Program Pascasarjana. Malang.

8. Soong K, Chen CA, Chang JC (2000) The very large poritide colony at Green Island, Taiwan. Coral Reefs. 19: 42.

9. Krishnamoorthi A, Selvakumar S (2012) Seasonal fluctuation of zooplankton community in relation to certain physicochemical parameters of Veeranam Lake in Cuddalore District, Tamil Nadu. International Journal of Research in Environmental Science and Technology. 2 (2): 22-26.

10. Leksono AS (2007) Ekologi Pendekatan Deskriptif dan Kuantitatif. Bayu Media Publishing. Malang.

11. Krebs CJ (1978) Ecology the Experimental Analysis of Distribution. Pearson Publishing. Singapore. 